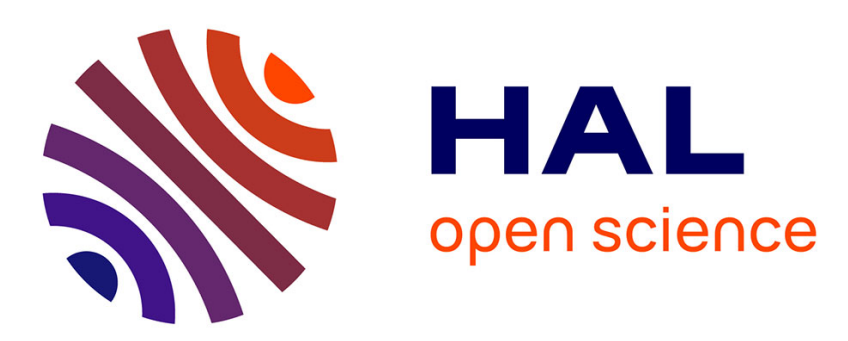

\title{
Assessing the Effect of Temperature on Degradation Modes of PV Panels
}

Bechara Nehme, Nacer K M'Sirdi, Tilda Akiki, Barbar Zeghondy

\section{To cite this version:}

Bechara Nehme, Nacer K M'Sirdi, Tilda Akiki, Barbar Zeghondy. Assessing the Effect of Temperature on Degradation Modes of PV Panels. REDEC'20 the International Conference on Renewable Energy for Developing Countries, Mar 2020, Marrakech, Morocco. hal-02486434

\section{HAL Id: hal-02486434 \\ https://hal.science/hal-02486434}

Submitted on 21 Feb 2020

HAL is a multi-disciplinary open access archive for the deposit and dissemination of scientific research documents, whether they are published or not. The documents may come from teaching and research institutions in France or abroad, or from public or private research centers.
L'archive ouverte pluridisciplinaire HAL, est destinée au dépôt et à la diffusion de documents scientifiques de niveau recherche, publiés ou non, émanant des établissements d'enseignement et de recherche français ou étrangers, des laboratoires publics ou privés. 


\section{Assessing the Effect of Temperature on Degradation Modes of PV Panels}

\author{
Bechara Nehme \\ Department of Electrical, \\ Telecommunications and \\ Computer Engineering \\ Holy Spirit University of Kaslik \\ (USEK) \\ Jounieh, Mount Lebanon - \\ Lebanon \\ becharanehme@usek.edu.lb \\ 0000-0002-4223-1224
}

\author{
Nacer K M'Sirdi \\ LIS UMR 7020 CNRS \\ Aix Marseille Universit'e, CNRS, \\ ENSAM, Universit'e de Toulon \\ 13397, Marseille France \\ nacer.msirdi@1sis.org
}

\author{
Tilda Akiki \\ Department of Electrical, \\ Telecommunications and \\ Computer Engineering \\ Holy Spirit University of Kaslik \\ (USEK) \\ Jounieh, Mount Lebanon - \\ Lebanon \\ tildaakiki@usek.edu.lb
}

\author{
Barbar Zeghondy \\ Department of Mechanical \\ Engineering \\ Holy Spirit University of Kaslik \\ (USEK) \\ Jounieh, Mount Lebanon - \\ Lebanon \\ barbarzeghondy@usek.edu.lb
}

\begin{abstract}
PV panels are affected by many degradation modes. We list the Potential Induced Degradation, the Light Induced Degradation, the UltraViolet Light Degradation, the Moisture Induced Degradation, and the Cell Cracks. These degradation modes are affected by external environmental conditions as irradiance, temperature and humidity. The common factor that affects the degradation modes is temperature. The degradation process follows an Arrhenius equation; it is exponentially related to temperature. In this paper we evaluate precisely the effect of temperature on the degradation process of $\mathrm{PV}$ panels.
\end{abstract}

Keywords - Temperature, Potential Induced Degradation, Light Induced Degradation, UltraViolet Degradation, Temperature, Efficiency, Mitigation

\section{INTRODUCTION}

People are relying more on the PV (Photovoltaic) production of energy. This is why reliability and efficiency of this energy source are becoming a concern. From here we focus on decreasing the degradation process of PV panels. In addition, the manufacturing of PV panels is expensive and needs rare raw materials like Indium, Silver, Germanium, and Gallium, or contain cancer causing elements like Cadmium and Lead [1].

In literature, researchers conducted many experiments to examine the effects of environmental and operational conditions on degradation modes. R. Swanson and al. explained the Potential induced degradation (PID) of PV panels; they showed how the system voltage affects PID [2]. Peter Hacke and al. showed the temperature effect on PID [3]. J Berghold and al. showed the effect of relative humidity on PID [4]. Bhushan Sopori and al. explained Light Induced Degradation (LID) in cSi cells [5]. A. Herguth and al. showed the effect of temperature on LID and defined new states of the Boron-Oxygen complex that is responsible of LID in c-Si cells [6]. A. Kolodziej explained the LID in a-Si solar cells which is called StaeblerWronski Effect (SWE). Kolodziej also showed the effect of illumination intensity on SWE [7]. F. J. Pern explained Ultraviolet light Degradation (UVD), he showed the degradation over time [8]. Jae-Seong Jeong and al. showed the effect of temperature on UVD [9]. F. J. Pern and al. showed the effect of UVD on the mathematical model of a PV cell [10]. Melissa A. Yaklin and al. showed the effect of humidity on TCO Transparent Conductive Oxide (TCO) [11]. Michael D. Kempe focused on the ingress of moisture into PV panels [12]. Jane Kapur and al. showed the geometrical repartition of moisture in the PV panel [13]. Sarah Kajari-Schröder and al. showed the geometrical and directional repartition of cracks in a PV panel [14]. S. KajariSchröder and al. explained when cracks become critical to PV cell [15]. M. Köntges and al. simulated the effect of cracks on power production [16]. In our previous works we modeled all degradations as function of time and of external environmental conditions [17], [18]. We also enhanced our model for taking into consideration the fact that external conditions vary during the day and during the year [19].

In this paper we assess the effect of temperature on degradation process. First we recall the equivalent circuit of a PV cell. Then we recall the degradation equations. This shows the main importance of our model to describe the systems behavior and aging.

\section{EQUiVALENT CiRCUIT OF A PV CELL}

The equivalent circuit of a PV cell is a current source ( $\mathrm{I}_{\mathrm{SC}}$ ) mounted in parallel with two diodes $\left(\mathrm{D}_{1}\right.$ and $\left.\mathrm{D}_{2}\right)$ and a shunt resistor $\left(R_{s h}\right)$. A series resistor $\left(R_{s}\right)$ is added to complete the model. The current generated $\mathrm{I}_{\mathrm{SC}}$ is proportional to the incident irradiance $\mathrm{G}$ in $\mathrm{W} . \mathrm{m}^{-2}$ and increases with temperature $\mathrm{T}$ in $\mathrm{K}$. The current flowing in the shunt resistor $\left(R_{s h}\right)$ represents the leakage current in the edge of the cell. The resistor $\mathrm{R}_{\mathrm{s}}$ models the electric contact resistance. The current I (in A) delivered to the load will become [1]: 


$$
\begin{aligned}
I=I_{S C}-I_{01}(\exp & \left.\left(\frac{e\left(V+I \times R_{S}\right)}{K \times T}\right)-1\right) \\
& -I_{02}\left(\exp \left(\frac{e\left(V+I \times R_{S}\right)}{2 \times K \times T}\right)-1\right) \\
& -\frac{\left(V+I \times R_{S}\right)}{R_{s h}}
\end{aligned}
$$

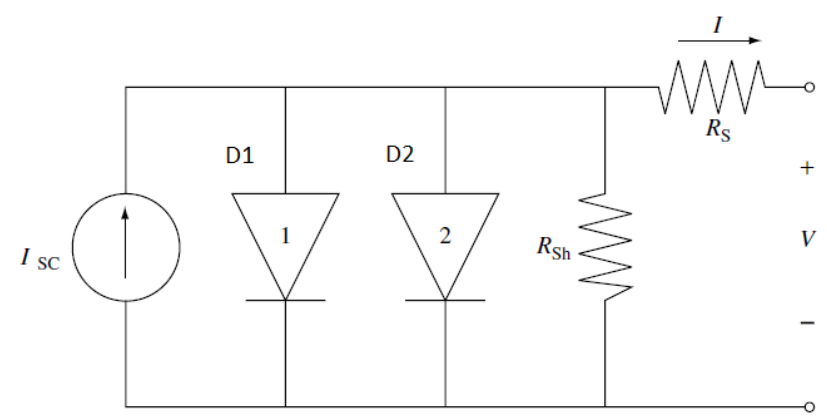

Figure 1 Equivalent Circuit of a PV cell.

Where:

$\mathrm{I}_{01}$ is the saturation current of diode $\mathrm{D}_{1}$ in $\mathrm{A}$

$\mathrm{I}_{02}$ is the saturation current of the diode $\mathrm{D}_{2}$ in $\mathrm{A}$

e is the electron charge $1.6 \times 10^{-19} \mathrm{C}$

$\mathrm{V}$ is the output voltage of the cell in $\mathrm{V}$

$\mathrm{K}$ is the Boltzmann constant $1.3806 \times 10^{-23} \mathrm{~J}^{-\mathrm{K}^{-1}}$

$\mathrm{T}$ is the temperature in $\mathrm{K}$.

\section{Modeling Degradation Modes}

When a PV cell is subject to degradation, its equivalent circuit is modified. In fact, the elements of the equivalent circuit will vary [17-18]. Qualitatively, The $I_{s c}$ and the $R_{s h}$ will decrease, The $\mathrm{I}_{01}$, the $\mathrm{I}_{02}$, and the $\mathrm{R}_{\mathrm{s}}$ will increase.

\section{A. PID Modeling}

PID increases the leakage current of a PV panel, it is modeled by a decrease in $\mathrm{R}_{\mathrm{sh}}$. It is explained by high difference in voltage between the active cell part and the edge of the panel. The voltage will cause electrons to move and to set a path between the $\mathrm{N}$ doped and $\mathrm{P}$ doped parts of the cell. It is also affected by relative humidity and follows an Arrhenius equation with an activation energy of $0.94 \mathrm{eV}$ [2-4]. The Arrhenius equation is described as following:

$$
A=K \times\left(\frac{-E_{a}}{R \times T}\right)
$$

Where:

$\mathrm{K}$ is the constant rate

$\mathrm{E}_{\mathrm{a}}$ activation energy in $\mathrm{eV}$

$\mathrm{R}$ gas constant $8.314 \mathrm{~J} \cdot \mathrm{mol}^{-1} \cdot \mathrm{K}^{-1}$

\section{B. LID Modeling}

LID increases $\mathrm{I}_{01}$ and $\mathrm{I}_{02}$. In reality, the recombination current is increased in the base of the cell. LID occurs to n-type emitter crystalline silicon cells and to amorphous silicon cells. In amorphous silicon cells it is known as the SWE. LID is manly affected by the intensity of illumination and follows an Arrhenius equation with an activation energy of $0.45 \mathrm{eV}$ [5-7].

\section{UVD Modeling}

The UV light affects the EVA encapsulation. Apparently the transmittance of the encapsulation will be affected. However, in modeling the $R_{s}$ and $R_{s h}$ resistors are affected by the discoloration of the EVA encapsulation. The latter is measured by a factor denoted Delta Yellowness Index (DYI) [8-10, 17]. The $R_{s}$ will increase and the $R_{s h}$ will decrease.

\section{MID Modeling}

The ingress of moisture in the panel affects the Transparent Conductive Oxide (TCO) layer which is used with thin film technologies. The TCO resistance increases as an effect of humidity. However, not all cells are affected alike due to unequal repartition of moisture in the panel. Water is more likely to be near the edges of the panel than at the center of the panel. The moisture reparation in the panel follows a sine equation. The water ingress in the panel follows an Arrhenius equation with an activation energy of $0.38 \mathrm{eV}$. And the degradation of TCO layer follows an Arrhenius equation with an activation energy of 0.91 $\mathrm{eV}$ [11-13].

\section{E. Cell Cracks}

Cell cracks happen manly due to snow accumulation on panels. The criticality of a crack depends on its orientation and if it has encountered freeze cycles. The cell cracks reduce the active cell area. Thus it decreases the short circuit current $\left(\mathrm{I}_{\mathrm{sc}}\right)$ and the recombination currents ( $\mathrm{I}_{01}$ and $\mathrm{I}_{02}$ ) [14-16].

TABLE 1 SUMMARY TABLE OF ALL DEGRADATION MODES AND THEIR FACTORS.

\begin{tabular}{|c|c|c|c|c|c|}
\hline Factors & $\boldsymbol{P I D}$ & $\boldsymbol{L I D}$ & $\boldsymbol{U V D}$ & $\boldsymbol{M I D}$ & Cell Cracks \\
\hline Temperature & $R_{\text {sh }}$ Decr & $\begin{array}{c}I_{01} \text { Incr } \\
I_{02} \text { Incr }\end{array}$ & $\begin{array}{c}R_{S} \text { Incr } \\
R_{s h} \text { Decr }\end{array}$ & $R_{S}$ Incr & - \\
\hline Humidity & $R_{\text {sh }}$ Decr & - & - & $R_{S}$ Incr & - \\
\hline Irradiance & - & $I_{01}$ Incr & $\begin{array}{c}R_{S} \text { Incr } \\
I_{02} \text { Incr }\end{array}$ & - & - \\
\hline Snow, freeze & - & - & - & - & $\begin{array}{c}I_{S C} \text { Decr } \\
I_{01} \text { Decr } \\
I_{02} \text { Decr }\end{array}$ \\
\hline
\end{tabular}

\section{Modeling Degradation Modes}

In this section we give the degradation equations. These equations describe the elements of the equivalent circuit according to external environmental conditions, operation, and events. The short circuit current is given by the following formula:

$$
I_{S C, \text { deg }}=I_{S C, T 1 \text { ref }} \times\left(1-\frac{A_{\text {inactive }}}{A_{\text {total }}}\right)
$$

Where:

I $_{\mathrm{SC}, T 1, \mathrm{ref}}$ is The Short Circuit current in Standard Test Conditions (STC) conditions in A

$A_{\text {inacive }}$ is The inactive cell area in $\mathrm{cm}^{2}$

$\mathrm{A}_{\text {total }}$ is The total cell area in $\mathrm{cm}^{2}$ 
As a function of time the value of the saturation current of diode $\mathrm{D}_{1}$ of a degraded cell is expressed by:

$$
\begin{aligned}
I_{01, \text { deg }}=\left(I_{01, T 1 \text { ref }}\right. & \left.+1.11 \times 10^{-10} \times \frac{G}{1000} \times \exp \left(\frac{-43268}{R \times T}\right) \times t\right) \\
\times & \left(1-\frac{A_{\text {inactive }}}{A_{\text {total }}}\right)
\end{aligned}
$$

Where:

$\mathrm{I}_{01, \mathrm{~T} 1 \text {,ref }}$ is the saturation current of diode $\mathrm{D}_{1}$ in STC in A

$\mathrm{G}$ is the actual irradiance in W. $\mathrm{m}^{-2}$

$\mathrm{R}$ is the Gas constant $8.314 \mathrm{~J} \cdot \mathrm{mol}^{-1} \cdot \mathrm{K}^{-1}$

$\mathrm{t}$ is Time in $\mathrm{s}$.

The same calculation is made to the saturation current of diode $\mathrm{D}_{2}, \mathrm{I}_{02, \mathrm{deg}}$ with an ideality factor of 2 .

The DYI is given by:

$D Y I=5.68 \times 10^{11} \times \exp \left(\frac{-90000}{R \times T_{\text {avg }}}\right) \times G_{\text {avg }} \times \log \left(\frac{t}{3600}\right)$

Where:

$\mathrm{T}_{\text {avg }}$ is the average temperature in $\mathrm{K}$

$\mathrm{G}_{\text {avg }}$ average Irradiance in W. $\mathrm{m}^{-2}$

As a function of time the value of the series resistor $R_{s, d e g}$ of a degraded cell is expressed by:

$$
R_{s}=\left(R_{s, T 1 \text { ref }}+9.9 \times 10^{-3} \times D Y I\right)
$$

Where, $\mathrm{R}_{\mathrm{s}, \mathrm{Tl} \text {,ref }}$ is the series resistance in STC in $\Omega$

As a function of time the value of the shunt resistor $R_{\text {sh,deg }}$ of a degraded cell is expressed by:

$R_{\text {sh,deg }}$

$=\frac{\left(R_{\text {sh }, \text { T1ref }}-193 \times D Y I\right)}{\left(7 \times 10^{-6} \times V_{\text {op }}^{2} \times R H^{2} \times \operatorname{exo}\left(\frac{-90700}{R \times T_{\text {avg }}}\right) \times t^{2}\right)\left(R_{\text {sh }, \text { T1ref }}-193 \times D Y I\right)+1}$

Where:

$\mathrm{R}_{\text {sh,T1,ref }}$ is the shunt resistance in $\Omega$

$\mathrm{V}_{\mathrm{op}}$ is the Operation voltage of the panel in $\mathrm{V}$

RH is the Relative humidity

We can see clearly in the above equations that temperature affects the elements of the equivalent circuit of PV panels by an exponential factor. The actual temperature also affects any resistor by increasing its value. We can see that all degradation modes are temperature and time dependent. From here we must evaluate the power generated by a panel in order to assess the effect of temperature on the efficiency of the panel. Thus, we will use our developed model to simulate the power produced by a Panel over time with different temperatures.

\section{Simulation ReSUlts}

The simulation is done for 10 years. Over the 10 years the panel operates at the MPP (Maximum Power Point). The average relative humidity of the location is $50 \%$. The maximum irradiance (summer, noon) of the location is $1000 \mathrm{~W} \cdot \mathrm{m}^{-2}$. And the operation voltage is $50 \mathrm{~V}$. We know that the model takes into consideration the variation of the relative humidity, the irradiance, and the temperature during the day and during the year.

In order to assess quantitatively the temperature effect on the degradation process of PV panel, it was varied first from $45^{\circ} \mathrm{C}$ to $49^{\circ} \mathrm{C}$ and the simulation results are presented in figure 2 . In figure 3 we varied the temperature from $35^{\circ} \mathrm{C}$ to $39^{\circ} \mathrm{C}$. In figure 4 we varied the temperature from $25^{\circ} \mathrm{C}$ to $29^{\circ} \mathrm{C}$.

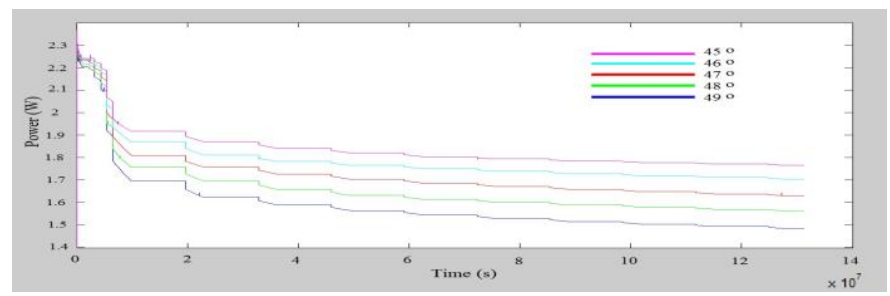

Figure 2 Power Output for a variation in temperature from $45^{\circ} \mathrm{C}$ to $49^{\circ} \mathrm{C}$

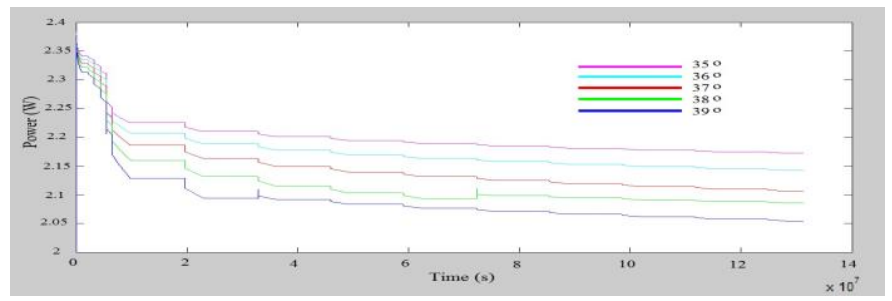

Figure 3 Power output for a variation in temperature from $35^{\circ} \mathrm{C}$ to $39^{\circ} \mathrm{C}$.

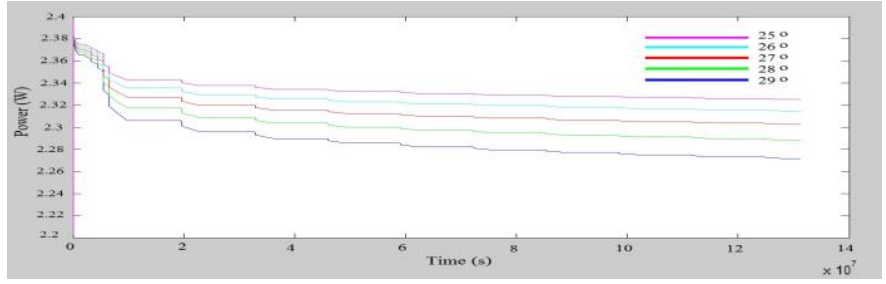

Figure 4 Power output for a variation in temperature from $25^{\circ} \mathrm{C}$ to $29^{\circ} \mathrm{C}$.

\section{DISCUSSION}

We can see clearly that with high temperature high degradation process occurs. In fact, the degradation is exponentially linked to the temperature value. We can see also that the most power loss occurs in the first two years.

Now let's assess the reduction of temperature. Calculating the mean percentage of power loss reduction when decreasing the temperature of $1^{\circ} \mathrm{C}$ for high temperatures $\left(45^{\circ} \mathrm{C}\right.$ to $\left.49^{\circ} \mathrm{C}\right)$ we get: $\mathrm{R}=0,025=2,5 \%$. This mean for each degree of reduction the degradation process will be mitigated by $2.5 \%$. The same calculation is made for the range of middle temperature $\left(35^{\circ} \mathrm{C}\right.$ to $39^{\circ} \mathrm{C}$ ) we find $\mathrm{R}=0,0094=0,94 \%$. And for the low temperature range $\left(25^{\circ} \mathrm{C}\right.$ to $\left.29^{\circ} \mathrm{C}\right)$ we find $\mathrm{R}=0,0065=0,65 \%$. Analyzing these results gives us an image on the reduction effect of temperature on degradation. We can see that a reduction in $1^{\circ} \mathrm{C}$ when operating at high temperature mitigates the degradation by $2.5 \%$. However, a reduction of $1{ }^{\circ} \mathrm{C}$ in middle and low temperature ranges only mitigates the degradation by $0.94 \%$ and $0.65 \%$ respectively. This leads to focusing on reducing the temperature during high ranges times. In details, for a $47^{\circ} \mathrm{C}$ the panel loses $30.65 \%$ of its initial efficiency. If we decrease the temperature by $1{ }^{\circ} \mathrm{C}$; for $46^{\circ} \mathrm{C}$ the panel loses $27.63 \%$ of its initial efficiency. However, when working on low temperature ranges, the panel looses $2,4 \%$ and $1.95 \%$ for $27^{\circ} \mathrm{C}$ and $26^{\circ} \mathrm{C}$ respectively. For $1^{\circ} \mathrm{C}$ of temperature reduction, the mitigation of degradation is more important for higher temperatures. 


\section{CONCLUSION}

In previous works we have built a precise model of PV panel degradation modes. Degradation is affected by external conditions like temperature, humidity, irradiance and by operational conditions. In this paper, we assess the effect of temperature on degradation mechanism. We found that a reduction in temperature of $1^{\circ} \mathrm{C}$ reduces the degradation process unequally when operating in high or low temperature ranges. From here emerges a recommendation for future works that any attempt to temperature reduction must be enrolled in high temperature ranges.

\section{REFERENCES}

[1] A. Luqueand and S. Hegedus, Handbook of Photovoltaic Science and Engineering. Wiley, 2003.

[2] R. Swanson, M. Cudzinovic, D. DeCeuster, V. Desai, J. J"urgens, N. Kaminar, W. Mulligan, L. Rodrigues-Barbarosa, D. Rose, D. Smith et al., "The surface polarization effect in highefficiency silicon solar cells," in 15th PVSEC, 2005.

[3] P. Hacke, K. Terwilliger, R. Smith, S. Glick, J. Pankow, M. Kempe, S. Bennett, and M. Kloos, "System voltage potential-induced degradation mechanisms in pv modules and methods for test," in Photovoltaic Specialists Conference (PVSC), 2011 37th IEEE. IEEE, 2011, pp. $000814-000820$.

[4] S. Pingel, O. Frank, M. Winkler, S. Daryan, T. Geipel, H. Hoehne, and J. Berghold, "Potential induced degradation of solar cells and panels," in Photovoltaic Specialists Conference (PVSC), 2010 35th IEEE. IEEE, 2010, pp. 002 817-002 822.

[5] B. Sopori, P. Basnyat, S. Devayajanam, S. Shet, V. Mehta, J. Binns, and J. Appel, "Understanding light-induced degradation of c-si solar cells," in Photovoltaic Specialists Conference (PVSC), 2012 38th IEEE. IEEE, 2012, pp. 001 115-001 120.

[6] A. Herguth, G. Schubert, M. Kaes, and G. Hahn, "Avoiding boronoxygen related degradation in highly boron doped cz silicon," in 21rt EU-PVSEC, 2006.

[7] A. Kołodziej, "Staebler-wronski effect in amorphous silicon and its alloys," Opto-electronics review, vol. 12, pp. 21-32, 2004.

[8] F. Pern, "Factors that affect the eva encapsulant discoloration rate upon accelerated exposure," Solar energy materials and solar cells, vol. 41, pp. 587-615, 1996.

[9] J.-S. Jeong, "Field discoloration analysis and uv/temperature accelerated degradation test of eva for pv," in 39th PVSC, 2013, pp. 3010-3013.
[10] F. Pern, Czanderna, AW, Emery, KA, Dhere, and RG, "Weathering degradation of eva encapsulant and the effect of its yellowing on solar cell efficiency," in Photovoltaic Specialists Conference, 1991., Conference Record of the Twenty Second IEEE. IEEE, 1991, pp. 557-561.

[11] Y. Melissa, S. Duane, N. Kirsten, G. Jennifer, and S. Chad, "Impacts of humidity and temperature on the performance of transparent conducting zinc oxide," in Photovoltaic Specialists Conference (PVSC), 2010 35th IEEE. IEEE, 2010, pp. 002 493-002 496.

[12] Kempe and Michael, "Control of moisture ingress into photovoltaic modules," in Photovoltaic Specialists Conference, 2005. Conference Record of the Thirty-first IEEE. IEEE, 2005, pp. 503-506.

[13] J. Kapur, J. L. Norwood, and C. D. Cwalina, "Determination of moisture ingress rate through photovoltaic encapsulants," in 39th IEEE Photovoltaic Specialists Conference (PVSC),. IEEE, 2013, pp. 3020-3023.

[14] S. Kajari-Schroder, I. Kunze, U. Eitner, and M. Kontges, "Spatial and directional distribution of cracks in silicon pv modules after uniform mechanical loads," in Photovoltaic Specialists Conference (PVSC), 2011 37th IEEE. IEEE, 2011, pp. 000 833-000 837.

[15] Kajari-Schr"oder, I. Kunze, and M. K" ontges, "Criticality of cracks in pv modules," in SiliconPV, 2012, pp. 658-663.

[16] M. K"ontges, I. Kunze, S. Kajari-Schr"oder, X. Breitenmoser, and B. Bjørneklett, "The risk of power loss in crystalline silicon based photovoltaic modules due to micro-cracks," Solar Energy Materials and Solar Cells, vol. 95, pp. 1131-1137, 2011.

[17] B. Nehme, N. K. M'Sirdi, T. Akiki, and A. Naamane, "Contribution to the modeling of ageing effects in PV cells and modules," Energy Procedia, vol. 62, pp. 565-575, 2014.

[18] B. Nehme, N. K. Sirdi, and T. Akiki, "A geometric approach for pv modules degradation," in REDEC-2014, 2014.

[19] Nehme, B. F., Akiki, T. K., Naamane, A., \& M'Sirdi, N. K. (2017). Real-time thermoelectrical model of PV panels for degradation assessment. IEEE Journal of Photovoltaics, 7(5), 1362-1375. 